\title{
PRESCHOOLERS EXPLORING THE RURAL ENVIRONMENT
}

\author{
MARIA DANIELA MĂRGINEAN \\ Kindergarten with Normal Programme Lechința, Mureș County, Romania, e-mail: danamar2008@yahoo.com
}

\section{RALUCA-CLAUDIA CASSIANU}

Babeş-Bolyai University, Faculty of Psychology and Sciences of Education, Department of Exact Sciences Didactics, Cluj-Napoca, Romania, e-mail: cassianu.raluca@yahoo.com

(Received: June 2017; in revised form: August 2017)

\begin{abstract}
This paper presents an experimental research made up in 2016-2017 school year with a major group of 16 children from the Kindergarten with Normal Programme in Lechința, Mureș County, Romania. The following assumption was attested: "If the preschoolers are involved in the learning activities where they study the rural environment in a direct and systematic way, under a specialised pre-school education teacher's coordination, then they can acquire a large number of correct skills and they form attitudes and behaviours suitable for the environment they inhabit". In the organised didactic experiment, we administered an initial test, we involved the preschoolers in many learning activities and finally we administered another test. The registered results at the experimental group were effective for the children, observing they achieved a great progress, expressed through a large number of skills, compared to the initial stage (level). We concluded that the research hypothesis was confirmed.
\end{abstract}

Keywords: visit, hiking, observation in nature, learning through experience, activity in field

\section{INTRODUCTION}

The preschoolers show curiosity regarding the environment in which they live, they always search for new places, they analyse them with great interest, but often, they form wrong representations about what they investigate. We often find out in the didactic activity the fact that the preschoolers have little knowledge about this environment and about its 
organisation and operation, even if they come from the rural areas. We often receive wrong answers to simple questions, that indicating an incomplete knowledge about the environment in which they live and a misunderstanding of some processes and phenomena which they observe.

In the Preschoolers' Learning Curriculum (2008) in Romania, it is recommended that the environment is studied by children and methods of studing it are suggested. Starting from these findings and recommendations, we realized a study referring to the way in which an effective exploitation of the environment by the pre-schoolers could be realised and how they can form some abilities, which are the basis of the key skills mentioned in the National Education Law (2011).

Our awareness of these issues and of other purposes made us identify those ways through which the preschoolers could faster discover information about the rural area and act inside it in an adequate way. In order to achieve the proposed objectives, we organised a series of learning activities in which the preschoolers explored directly the rural area.

In the present study, we analyse the experience learning activities in which the pre-schoolers were involved (i.e. taking part in many visits and hiking in Lechinţa, Mureş County) and their results. The aim of this research is to test the following hypothesis: if the preschoolers are involved in learning activities where they study the rural area in a direct and systematic way, under a specialised pre-school education teacher's coordination, then they can acquire a large number of correct skills and they form attitudes and behaviours suitable for the environment they inhabit.

\section{THEORETICAL BACKGROUND}

In Romania's specialised literature, there are recommendations referring to the way of organising the activities of observation in nature (Ciascai, 2001, 2007; Ignat et al., 2010; Glava et al., 2004; Tătaru et al., 2014) in order to facilitate the application of provisions from the Preschool Education Curriculum (2008). The didactic works focus on environmental knowledge objectives, on the education values regarding the environment and the steps which should be done for their achievement (Dulamă, 2010, 2011, 2012) and also on environmental protection measures (Dulamă et al., 2010).

In order to ensure a proper learning context, it is recommended that the environmental exploration to be realised through some extracurricular activities (visits, hiking) where children could directly analyse the environmental components and the relationship between them (Dulamă, 2004; Dulamă and Buda, 2014; Dulamă et al., 2016; Dulamă et al., 2017). In specialised works and studies, it is argued that, in environmental exploration, children need to be guided by teachers' questions (Ciascai, 
2001, 2007; Dulamă, 2008; Glava et al., 2014). The efficiency of environmental education is ensured by involving children in different games in nature (Dulamă and Fărcăşiu, 2010; Ignat et al., 2010; Glava et al., 2014) and in group activities (Dulamă, 2008; Tătaru et al., 2014).

\section{METHOD AND MATERIAL}

The research was realised in the 2016-2017 school year, at the Kindergarten with Normal Programme in Lechința, Mureș County.

Research methods. The experimental research included three stages: (1) initial testing, (2) systematisation of learning activities, (3) final testing. In 16 learning activities, the preschoolers explored: the environmental (natural, anthropic, territorial and social) components of Lechinţa village, different environments (pasture, grassland, hardwood forest, rivers, vegetable and greens garden, orchard, bovine farm), a rural farmhouse, the street and the cobbled roads, etc. All the data was collected in the field through observation and individual and collective conversation methods. Data processing was completed through statistic methods, its interpretation through logical methods and its graphical representation through the Excel programme.

The participants. The experimental group was made up of 16 preschoolers from the major group ( 8 girls and 8 boys) of the Kindergarten with Normal Programme in Lechința Village, Mureș County. These children accomplished the established criteria at the beginning of the experiment (age, the attending of Kindergarten): they had an average and heterogeneous level of training and their psychical and physical level of development was in accordance with the age they had. These preschoolers participated, together with Maria Daniela Mărginean, the preschool education teacher, in extracurricular activities - visits and hiking - realized in Lechința village, for the exploration of the rural environment.

The research material is represented by the children's answers at the teacher's questions during the visits and hiking and by their results at the initial and final examination.

\section{DISCUSSIONS AND RESULTS}

The learning activities. Each activity, based on studying one of the rural environmental aspects in Lechința village, was organised in three stages. In the first stage, called Preparing the preschoolers for going out in the field, we discussed with them about some environmental components and their features, and we verified some previous skills. 
In the second stage, Going out in the field, we organised the visit in the village hearth and the hiking outside the hearth. The preschoolers observed the environmental components and their features, guided by teacher's questions.
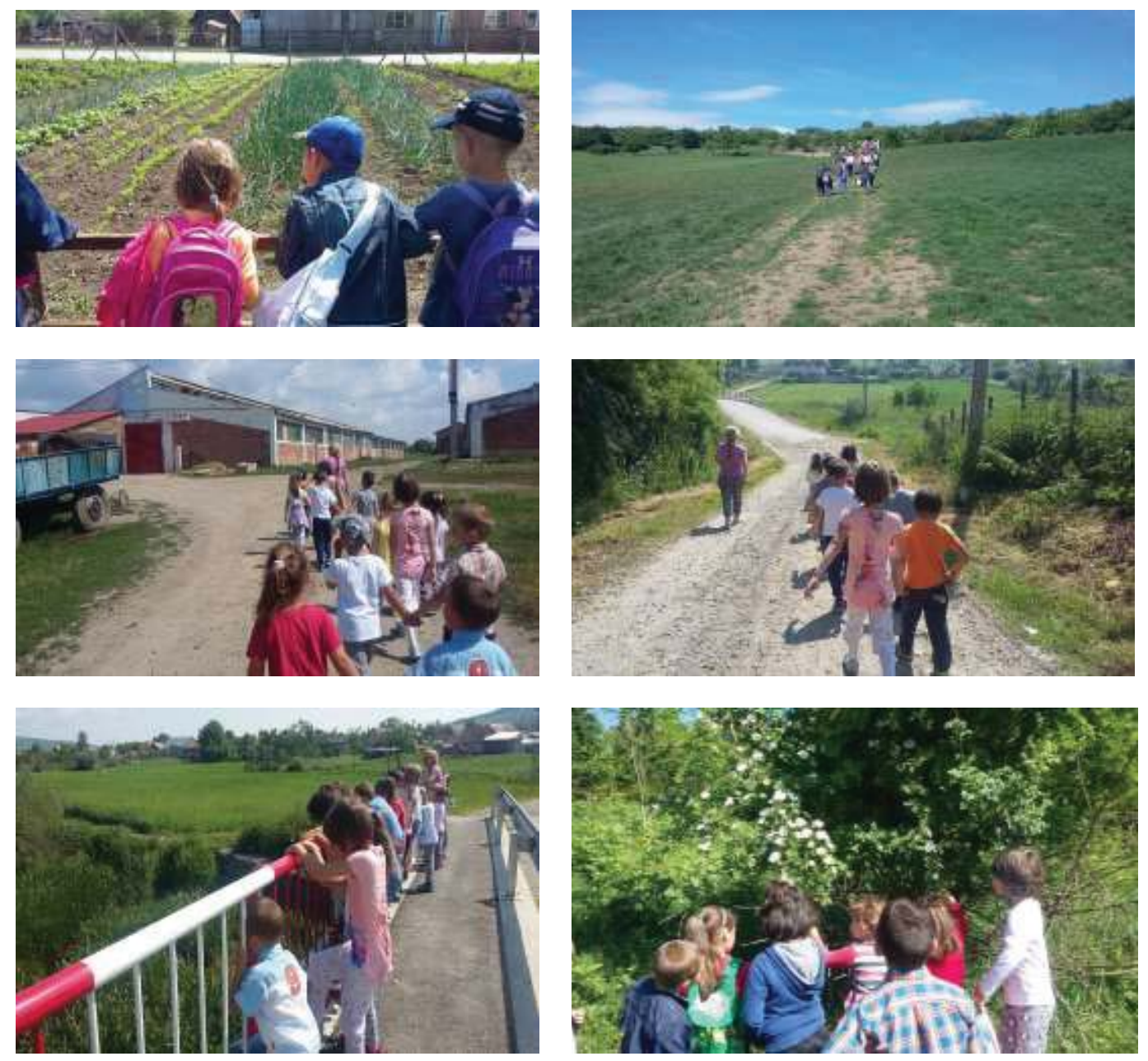

Fig. 1. Preschoolers' environmental exploitation in Lechința village

They asked some questions about the aspects they noticed. Each field activity included many learning sequences where we targeted the acquiring of a smal number of skills, because the preschoolers cannot focus their attention for a long time, and thus to enable them to receive and learn new information. In the third stage, Knowledge revision, taking place in the Kindergarten, we discussed with the preschoolers about the aspects they 
had observed in the field. We insisted on repeating the essential skills, attitudes, and adequate behaviours to the environment.

Initial testing results (Appendix 1 ) and final testing results (Appendix 2 ). After the initial testing, in September 2016, we transformed the scores into grades: 9-10 points equivalent to Very good grade $(F B)$; 7-8 points equivalent to Good grade $(B)$; 5-6 points equivalent to Sufficient grade $(S)$; under 5 points equivalent to Insufficient grade $(I)$. To the initial test, the preschoolers obtained the results represented in Figure 2. Referring to the knowledge about the rural area, the preschoolers obtained the following grades: $F B$ grade - a preschooler, $B$ grade -7 preschoolers, $S$ grade -5 preschoolers and $I$ grade - 3 preschoolers. These results indicated the necessity of the preschoolers' involvement into activities of exploring the rural area in order to get a better knowledge about it.

To the final test, the preschoolers got the following results: $F B$ grade - 10 preschoolers, $B$ grade -3 preschoolers, $S$ grade -3 preschoolers. The final testing results indicate an increase of the pre-schoolers' knowledge, compared to the initial test (Figure 2).

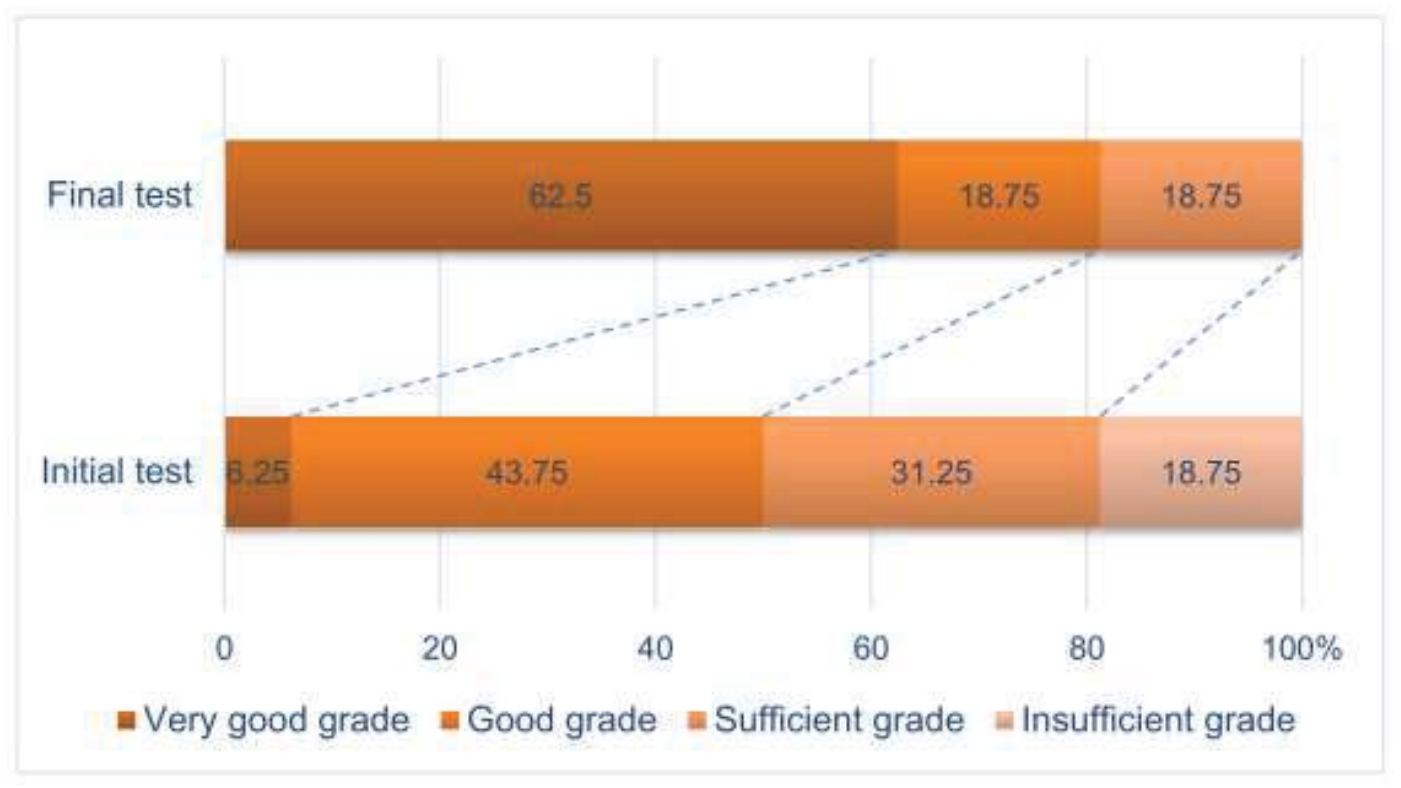

Fig. 2. The preschoolers' results to the both initial and final tests

\section{CONCLUSIONS}

At the end of this research, we noticed that preschollers' effective environmental exploration could be realised during visits and hiking, where they observed directly the enviromental components, its characteristics and the relashionships between them. During these activities organised in the 


\section{MARIA DANIELA MĂRGINEAN, RALUCA-CLAUDIA CASSIANU}

field, the preschoolers discover information, learn how to analyse and how to compare some environmental behaviours, to act, they achieve attitudes and appropriate behaviours for the area they inhabit.

The registered results to the experimental group show that the learning activities through experience were effective for the children. Their progress manifested through a large number of skills, compared to the initial stage (level) so, the hypothesis was confirmed: "If the preschoolers are involved in learning activities where they study the rural environment in a direct and systematic way, under a specialised pre-school education teacher's coordination, then they can acquire a large number of correct skills and they form attitudes and behaviours suitable to the environment they inhabit".

\section{References}

Ciascai, L. (2001). Introducere în didactica ştiinţelor. Didactica disciplinei "Ştiinţe". Cluj-Napoca: Editura Casa Cărţii de Ştiinţă.

Ciascai, L. (2007). Didactica ştiinţelor naturii. Cluj-Napoca: Editura Casa Cărţii de Ştiinţă.

Dulamă, M.E., \& Buda, M. (2014). Activități de explorare a pârâului Cundului cu elevii din clasa pregătitoare. In Maria Eliza Dulama, Oana-Ramona Ilovan, Gabriela Osaci-Costache, \& Liliana-Camelia Ciobanu, Tendinţe actuale în predarea şi învătarea geografiei. Contemporary Trends in Teaching and Learning Geography (pp. 166-176). Cluj-Napoca: Presa Universitară Clujeană.

Dulamă, M.E., \& Fărcăşiu, D. (2010). Utilizarea jocurilor şi exerciţiilor senzoriale în educaţia timpurie. In Maria Eliza Dulamă, Teodor Dumitru Vălcan (coord.), Cercetări, aplicaţii şi reflecţii despre educaţie. Cluj-Napoca: Editura Presa Universitară Clujeană, 64-71.

Dulamă, M.E. (2004). Modelul învăţării depline a geografiei. Cluj-Napoca: Editura Clusium.

Dulamă, M.E. (2008). Metodologie didactică. Teorie şi aplicaţii (Ediţia a 2-a). ClujNapoca: Editura Clusium.

Dulamă, M.E. (2010). Cunoaşterea şi protecţia mediului de către copii. ClujNapoca: Presa Universitară Clujeană.

Dulamă, M.E. (2011). Geografie și didactica geografiei pentru învăţământul primar şi preşcolar. Cluj-Napoca: Presa Universitară Clujeană.

Dulamă, M.E. (2012). Ştiinţe şi didactica ştiinţelor pentru învăţământul primar şi preşcolar. Cluj-Napoca: Presa Universitară Clujeană.

Dulamă, M.E., Ilovan O.-R., Magdaș, I., \& Răcășan, B. (2016). Is There Any Forestry Education In Romania? Geography Teachers' Perceptions, Attitudes 
and Recommendations. Studia Universitas Babeş-Bolyai, PsychologiaPaedagogia, LXI(1), 27-52.

Dulamă, M.E., Ilovan, O.-R., \& Magdaş, I. (2017). The Forests of Romania in Scientific Literature and in Geography. Teachers' Perceptions and Actions. Environmental Engineering and Management Journal, 16(1), 169-186.

Dulamă, M.E., Pop, A.M., \& Bozga, L. (2010). Connâitre et appliquer des mesures de l'environnement dans l'école primaire. Studia Universitas Babeş-Bolyai, Psychologia-Paedagogia, LV(1), 19-30.

Glava, A., Pocol, M., \& Tătaru, L.-L. (coord.) (2014). Educaţia timpurie. Ghid metodic pentru aplicarea curriculumului preşcolar. Piteşti: Editura Paralela 45.

Ignat, E., Stoian, L., Pitiu, A., Chira, E., Grama, F., Damian, A., Bodea, A., Tătaru, L., Nicolae, I, \& Manolache, A. (2010). Metodica activităţilor instructiveducative în grădiniţa de copii. Craiova: Sitech.

MECT (2012). Curriculum pentru învăţământul preşcolar. Bucharest.

Tătaru, L.-L., Glava, A., \& Chiș, O. (coord.) (2014). Piramida cunoșterii. Repere metodice în aplicarea curriculumului preşcolar. Piteşti: Editura Diamant.

\section{Appendix 1. The initial test}

I. Objective: the preschoolers will be able to recognise the cultivated plants from the rural area

1. Encircle with a red line the cultivated plants from the rural area.

2. Encircle with a green line the wild plants from the rural area.

II. Objective: the preschoolers will be able to recognise the specific animals from the rural area.

1. Encircle with a red line the domestic animals living in the rural area.

2. Encircle with a green line the wild animals living in the rural area.

III. Objective: the preschoolers will be able to recognise the typology of the rural area.

1. Encircle with a red line the pasture.

2. Encircle with a green line the grassland.

3. Encircle with a brown line the hardwood.

4. Encircle with a blue line the orchard.

5. Encircle with a black line the wheat field.

IV. Objective: the preschoolers will be able to recognise the appropriate behaviours to the environment. 


\section{MARIA DANIELA MĂRGINEAN, RALUCA-CLAUDIA CASSIANU}

1. Encircle with a green line the photos that show appropriate behaviours to the environment.

Correction standard (norm). 0.5 points are granted for a correct answer. An extra point is offered.

\section{Appendix 2: The final test}

I. Objective: the preschoolers will be able to recognise the cultivated plants from the rural area.

1. Encircle with a red line the cabbage, one of the cultivated plants in the rural area.

2. Encircle with a brown line the corn, one of the cultivated plants in the rural area.

3. Encircle with a black line the sunflower, cultivated plant in the rural area.

4. Encircle with a red line the vineyard, cultivated plant in the rural area.

5. Encircle with a green line the sloe, the fruits of a wild shrub from the rural area.

6. Encircle with a brown line the blackberries, the fruits of a wild shrub from the rural area.

7. Encircle with a red line the sweetbrier flowers, wild plant form the rural area.

II. Objective: the preschoolers will be able to recognise the specific animals form the rural area.

1. Encircle with a red line the cow, a domestic animal from the rural area.

2. Encircle with a brown line the goat, a domestic animal from the rural area.

3. Encircle with a black line the bee, a human-cared animal from the rural area.

4. Encircle with a green line the goat, a domestic animal from the rural area.

5. Encircle with a green line the boar, a wild animal living in the rural area.

6. Encircle with a red line the fox, a wild animal living in the rural area.

7. Encircle with a brown line the deer, a wild animal living in the rural area.

III. Objective: the preschoolers will be able to recognise the types of the rural area

1. Encircle with a red line the pasture. 
2. Encircle with a green line the grassland.

3. Encircle with a brown line the hardwood.

4. Encircle with a blue line the orchard.

5. Encircle with a black line the wheat field.

IV. Objective: the preschoolers will be able to recognise the appropriate behaviours to the environment.

1. Encircle with a green line the photos that show appropriate behaviours to the environment.

Correction standard (norm). 0.5 points are granted for a correct answer. An extra point is offered. 